\title{
Fatal Eustrongylidosis in a Young Wild Little Grebe (Tachybaptus ruficollis) from Japan
}

\author{
Koichi MURATA ${ }^{1)}$, Mitsuhiko ASAKAWA ${ }^{2)}$, Ayako NODA ${ }^{3)}$, \\ Tokuma YANAI $^{3)}$ and Toshiaki MASEGI ${ }^{3)}$ \\ 1) Kobe Municipal Oji Zoo, Nada, Kobe 657 \\ 2) Department of Parasitology, School of Veterinary Medicine, Rakuno Gakuen University, Ebetsu, Hokkaido 069 \\ 3) Department of Animal Pathology, Faculty of Agriculture, Gifu University, Gifu 501-11, Japan \\ (1997.7.14 received, 1997.7.24 accepted)
}

\section{野生カイツブリ若鳥の Eustrongylidosis による死亡例}

\author{
村田 浩-1)，浅川 満彦2)，野田 覀矢子 ${ }^{3)}$, 柳井 徳麿3)，栅木 利昭3) \\ 1）神戸市立王子動物園 テ 657 神戸市灘区王子町 3-1 \\ 2）酪農学園大学獣医学部寄生虫学教室 $\overline{0} 069$ 北海道江別市文京台緑町 582-1 \\ 3) 岐皋大学農学部家畜病理学教室 $=501-11$ 岐皁市柳戸 1-1
}

\begin{abstract}
A young male little grebe (Tachybaptus ruficollis), caught at Kobe in Hyogo Prefecture, Japan in December 1995, died of a severe infection with Eustrongylides tubifex Jägerskiöld 1909 (Nematoda: Dioctophymatoidea). Numerous nematodes were found in the lumen of the proventriculus, attaching to the mucosa, and some were penetrating into muscle layer. Histopathologically, severe inflammation was found around the nematodes. E. tubifex may be one of factors contributing to the mortality of wild little grebes.
\end{abstract}

Key words: Eustrongylides tubifex, little grebe, Nematoda

Jpn.J.Zoo Wildl.Med. 2(2): : 87-90, 1997

On December 7 1995, a young male little grebe ( $T a$ chybaptus ruficollis) was submitted to the veterinary hospital of Kobe Municipal Oji Zoo because of weakness and emaciation. This bird was captured at Kobe in Hyogo prefecture, Japan $\left(135^{\circ} 10^{\prime} \mathrm{E}, 34^{\circ} 41^{\prime} \mathrm{N}\right)$, but the precise information of the caught site was unclear. In spite of some medical treatment with the agents of antibiotics and vitamins at the zoo hospital, the bird died two days after arrival.

Necropsy was performed 12 hours after death. The body weight was $121 \mathrm{~g}$ and the body condition was poor based on its pectoral muscle. Grossly, a large number of nematodes, ranging from $30 \sim 40 \mathrm{~mm}$ in length, were found protruding into the lumen of the proventriculus. Some of them were penetrating deeply through muscle layer to the opposite serosa (Figure 1). The proventricular wall with nematodes was severely thickened and firm in consistency.

Proventriculus and liver were collected, and fixed in 10\% neutral buffered formalin. A part of them were then embedded in paraffin wax, cut into $5 \mu \mathrm{m}$ sections, and stained with hematoxylin and eosin. The rest of the fixed nematodes were removed from the proventiculus using a sharp knife and tweezers. As it was difficult to separate the nematodes within the wall of the proventriculus completely, fragmented parasites were separated and cleared in lacto 
Koichi MURATA et al.

-phenol solution for morphological examination by light microscopy. The specimens were deposited in Meguro Parasitological Museum (4-1-1, Shimo-Meguro, Meguro, Tokyo 153, Japan) with the accession number of MPM -Coll. No.19701.

Histopathologically, thickened proventricular wall contained many nematodes. A moderate to severe inflammatory reaction consisting of granulocytes, lymphocytes, plasmacytes and macrophages was found around the nematodes (Figure 2). The mucosal epithelium, with invasion of nematodes, revealed marked erosion and infiltration of granulocytes and lymphocytes. Many parasitic granulomas or abscesses containing nematodes were also observed in the muscle layer and subserosa with moderate fibrous reaction. The serosa of the proventriculus showed severe peritonitis.

Eustrongylides spp. (Dioctophymatoidea; Dioctophymatidae; Eustrongylinae) are commonly found in piscivorous birds such as herons, egrets and ducks [1-3]. It is supposed fishes may play an important role as transport hosts of Eustrongylides spp. [4-7]. At least 20 species of the genus Eustrongylides have been reported, but the classification were reexamined by Rautela and Malhotra [8] and Measures [9]. The nematodes isolated from an immature little grebe were similar to $E$. tricolor reported by Sugimoto [10] with its body length, copulatory bursa, and egg size.

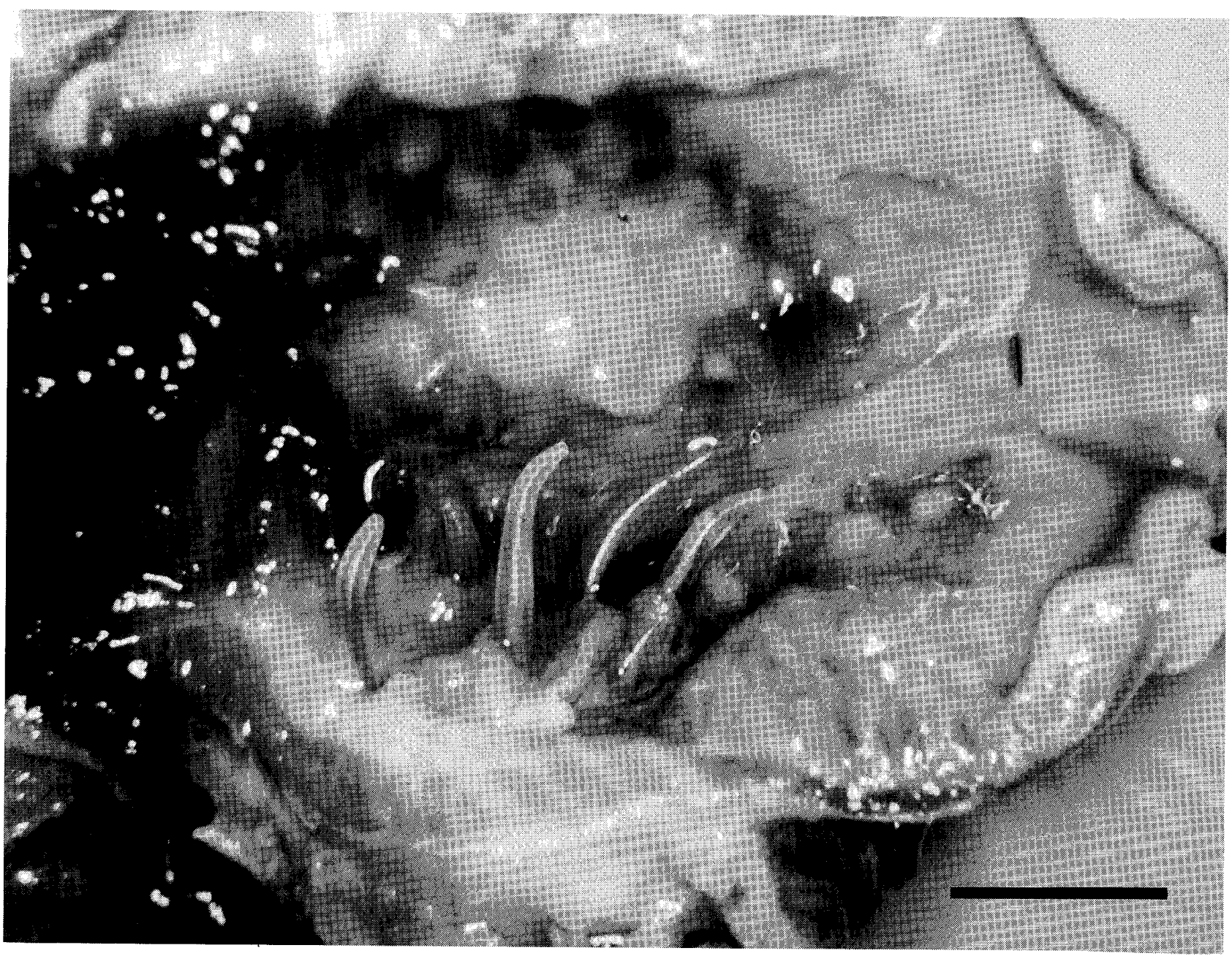

Figure 1.

The posterior or anterior end of the nematode parasites protruded into the proventricular lumen through the muscle layer from the proventicular serosa. Bar $=3 \mathrm{~mm}$. 


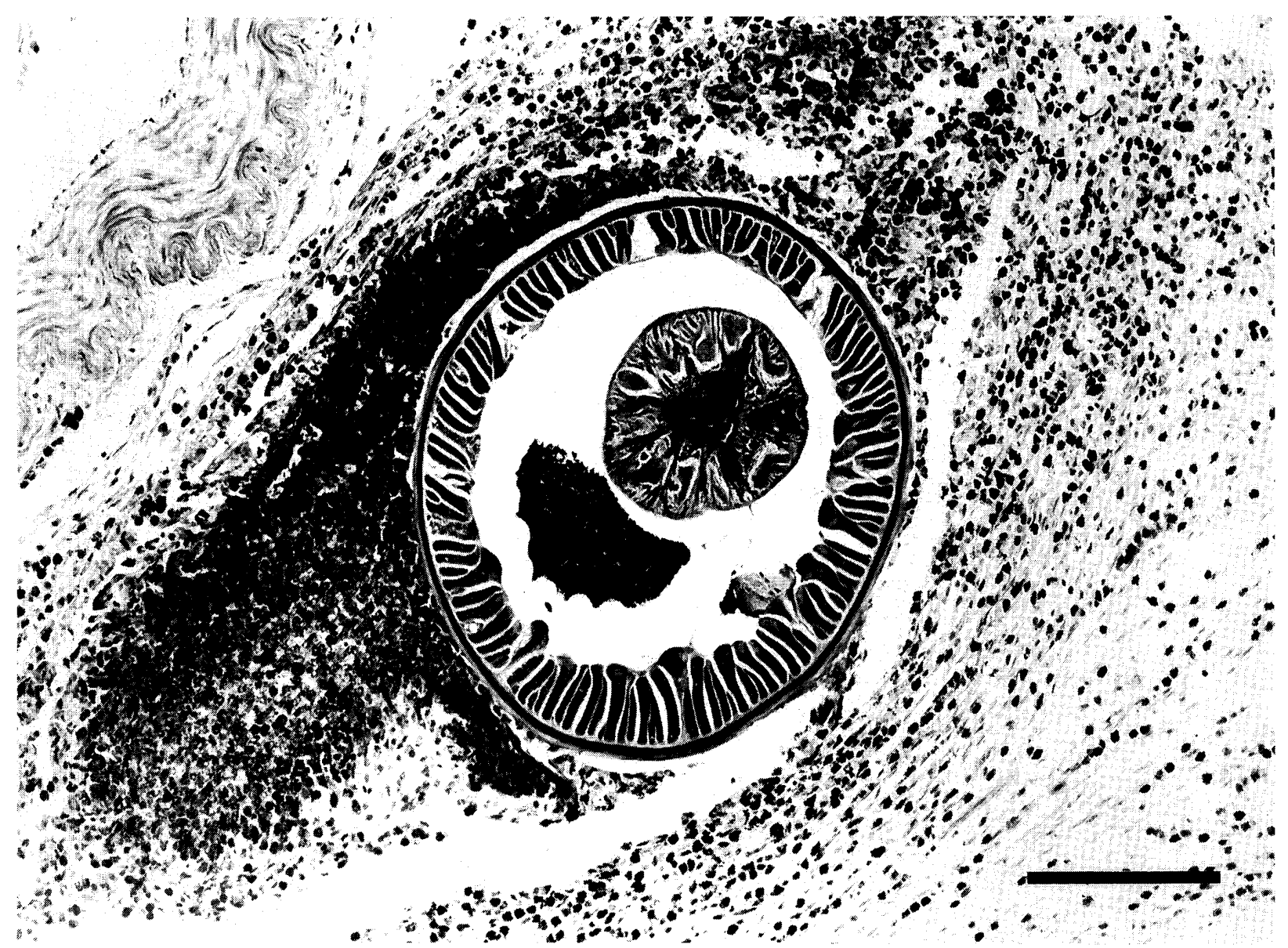

Figure 2.

A nematode penetrating into the subserosa. Severe inflammatory reaction was found around the nematode. H.E. stain. Bar $=100 \mu \mathrm{m}$.

However, Measures [9] suggested $E$. tricolor is a synonym of $E$. excisus Jägerskiöld, 1909. The new specific identification by Measures [9] is based on the size and morphology of the labial papillae of the inner and outer circles. As the papillae of the present specimens were unclear by light microscopic observation, more precise study under a scannig electron microscope was done, and this was identified as $E$. tubifex Jägerskiöld, 1909 in order to investigate anterior extremity with the papillae in two circles [11].

Fatal cases of eustrongylidosis in North American Ciconiiformes has been frequently reported $[6,7,12,13]$ and other fish eating birds has been well documented [2]

A few cases of Eustrongylides spp. infection and its path- ogenity in Japanese wild birds has been reported $[14,15]$. There is only one report of $E$. elegans infection in the birds belonging to the order Podicipediformes from Lake Biwa, Japan [16], but the lesions were not mentioned. The little grebe inhabits lakes and ponds and breed in Japan except the northern areas [17]. They feed on insects, larvae, molluscs, and small fish [18]. As the parasites were mature and eggs were detected from the female, it suggests that the little grebe may be a definitive host of $E$. tubifex and the infection probably occurs after feeding on infected freshwater fishes or invertebrates. Regarding the severe pathological changes in the proventriculus, it is supposed that the eustrongylid infection may be a fatal factor for the little 


\section{Koichi MURATA et al.}

grebe in the wild.

\section{要約}

野生カイツブリ (Tachybaptus ruficollis) 一羽が兵庫県下で衰弱 のために保護され死亡した。剖検により腺胃墏膜面に付着する 多数の線虫 (Eustrongylides tubifex) が認められ，筋層を貫通し て内腔に頭部もしくは尾部を露出していた。病理組織学的には 線虫が侵入した周囲組織に炎症性細胞浸潤を伴う高度な病変が 認められ，本線虫寄生が野生における死因のひとつになってい ると推察された。

キーワード : Eustrongylides tubifex，カイツブリ，線虫

\section{REFERENCES}

1. Flynn RJ. 1973. In Parasites of Laboratory Animals. The Iowa State University Press, Ames, Iowa.

2. Measures LN. 1988. Can J Zool 66: 2223-2232.
3. Spalding MG, Forrester DJ. 1993. J Wildl Dis 29: 250-260.

4. Davis JW, Anderson RC, Karstad L, Trainer DO. In Infectious and Parasitic Diseases of Wild Birds. The Iowa State University Press, Ames, Iowa.

5. Measures LN. 1988. Can J Zool 66: 2212-2222.

6. Spalding MG, Bancroft GT, Forrester DJ. 1993. J Wildl Dis 29: 237-249.

7. Wiese JH, Davidson WR, Nettles VF. 1977. J Wildl Dis 13: 376-382.

8. Rautela AS, Malhotra SK. 1984. Kor J Parasitol 22: 242-247.

9. Measures LN. 1988. Can J Zool 66: 885-895.

10. Sugimoto M. 1931. J Jpn Soc Vet Sci 10: 57-67.

11. Asakawa M, Kimoto Y, Murata K. 1997. J Vet Med Sci (in press).

12. Bowdish BS. 1948. Auk 65: 602 .

13. Locke LN. 1961. Avian Dis 5: 135.

14. Morishita K. 1928. Zool Mag 40: 12-16 (in Japanese).

15. Yamaguti S. 1941. Jpn J Zool 9: 441-480.

16. Yamaguti S. 1935. Jpn J Zool 6: 403-431.

17. Sonobe K, Robinson JW. 1982. In A Field Guide to the Birds of Japan. Wild Bird Society of Japan, Tokyo.

18. del Hoyo J, Elliott A, Sargatal J. 1992. In Handbook of the Birds of the World. Vol.1, Lynx Edicions, Barcelona. 